\title{
Leptospira interrogans serogroup Pomona strains isolated from river buffaloes
}

\author{
Israel Barbosa Guedes ${ }^{1}$ (D) - Gisele Oliveira de Souza ${ }^{1}$ (D) Juliana Fernandes de Paula Castro ${ }^{1}$ (D) \\ Matheus Burilli Cavalini ${ }^{1}$ (D) - Antônio Francisco de Souza Filho ${ }^{1}$ (D) - Anderson Luiz Pinheiro Maia ${ }^{2}$. \\ Eduardo Alberto dos Reis ${ }^{3} \cdot{\text { Adriana } \text { Cortez }^{3} \text { (D) } \cdot \text { Marcos Bryan Heinemann }}^{1}$ (D)
}

Received: 20 April 2020 / Accepted: 14 February 2021 / Published online: 5 March 2021

(C) The Author(s), under exclusive licence to Springer Nature B.V. part of Springer Nature 2021

\begin{abstract}
At present, little is known regarding the prevalence of buffalo leptospirosis worldwide, especially with respect to which Leptospira strains may infect this animal species. Furthermore, most investigations into this disease in buffaloes have only been performed with serological studies. In Brazil, particularly in the Amazon, buffalo production is growing and is just as important as cattle production, although few studies have been performed on buffalo compared to cattle. Thus, the aim of this study was to isolate and characterise Leptospira strains from river buffaloes raised in the Brazilian Amazon region. We collected 109 kidney samples from slaughtered buffaloes raised in the Amazon Delta region of Brazil. The samples were analysed by bacteriological culture for the isolation of leptospires, and the obtained isolates were serologically and molecularly characterised by microscopic agglutination test (MAT), DNA sequencing and multiple locus variable-number tandem repeat analysis (MLVA). Five isolates were obtained, and in serogrouping analyses, these isolates were only reactive for the Pomona serogroup, with an observed titre of 25,600. The DNA sequencing results revealed that all the isolates belonged to the species Leptospira interrogans, and the MLVA results showed that the VNTR loci 4, 7 and 10 profile of all the isolates was 4-1-10. In this study, we observed that Pomona serogroup strains circulate in buffaloes in the Amazon, showing that in Brazil, buffaloes can be affected by Leptospira strains other than the Sejroe group, which are adapted to cattle.
\end{abstract}

Keywords Leptospirosis · Isolation · DNA sequencing · Buffalo · Amazon

\section{Introduction}

Bacteria of the genus Leptospira are fastidious microorganisms that require a range of nutrients in culture media for their isolation and maintenance, which is one of the major difficulties in the isolation of leptospires (Faine et al. 1999). However, due to advancements in molecular biology, DNA sequencing

Marcos Bryan Heinemann

marcosbryan@usp.br

1 Laboratório de Zoonoses Bacterianas, Departamento de Medicina Veterinária Preventiva e Saúde Animal, Faculdade de Medicina Veterinária e Zootecnia, Universidade de São Paulo, São Paulo, SP, Brazil

2 Médico Veterinário, Auditor Fiscal Agropecuário, Agência de Defesa e Inspeção Agropecuária do Estado do Amapá, Macapá, AP, Brazil

3 Curso de Medicina Veterinária, Universidade Santo Amaro, São Paulo, SP, Brazil currently allows for the species-level identification of leptospires from clinical specimens without the need for isolation (Loureiro et al. 2016; Guedes et al. 2019). Despite this, the isolation of Leptospira cannot be completely replaced since isolates are extremely important for phylogenetic (Vincent et al. 2019), virulence (Thibeaux et al. 2018) and epidemiological studies (Pinto et al. 2017) and are especially important for vaccine development (Zarantonelli et al. 2018).

Leptospirosis has an important impact on public health because it is a zoonosis. This is noticeable when, in an ecosystem, humans, livestock and wild animals have antibodies against the same serogroups of Leptospira spp., resulting from human exposure to urine or tissues of infected animals (Faine et al. 1999; Assenga et al. 2015). In addition, the interpretation of serology results considering animals and humans provides valuable information for control measures (Assenga et al. 2015).

Buffalo leptospirosis remains poorly studied in relation to cattle worldwide, but it is known that leptospirosis causes 
reproductive disorders, such as abortion, in these animals (Marianelli et al. 2007; Balakrishnan et al. 2014). Recently, in the Amazon Delta region, leptospires species were identified in the kidneys and uterus of buffaloes for the first time, demonstrating the presence of $L$. interrogans and L. borgpetersenii (Guedes et al. 2020a). Serological studies conducted in the Amazon have shown a predominance of the Sejroe serogroup in buffaloes of this region (Viana et al. 2009; Rocha et al. 2019; Guedes et al. 2020b), but in the Northeast region of Brazil, the Pomona serogroup has been reported as being highly prevalent in buffaloes (Pimenta et al. 2019). Regardless of Brazil being one of the largest buffalo producers in the world, few studies have described the isolation of leptospires from buffaloes in this country, with a single isolate belonging to the Sejroe serogroup having been obtained from buffaloes in southeastern Brazil (Vasconcellos et al. 2001).

In the Amazon, the belief that buffaloes are resistant to diseases has resulted in the neglect of leptospirosis, and a lack of Leptospira isolation has resulted in the epidemiological status of this disease remaining unknown in this region. Thus, the goal of this study was to isolate and characterise leptospires from buffaloes raised in remote areas of the Amazon, mainly in the region known as the Amazon Delta, a region for buffalo production in Brazil that remains poorly studied.

\section{Materials and methods}

\section{Area of study}

The investigation area of this study, the Amazon Delta, is in extreme north of Brazil between the States of Pará and Amapá and is the largest and most important buffalo-producing region in Brazil (Fig. 1). This region has a humid equatorial climate that is typical of the Amazon region and is characterised by high temperatures, humidity and rainfall. Buffaloes are primarily produced for their meat, a practice that has become one of the most important activities in this region, and buffaloes are adapted to the environmental conditions of this region.

\section{Sample collection}

In this study, we collected 109 kidney pieces from buffaloes slaughtered in a Macapá microregion (Brazil) slaughterhouse that receives animals raised in the Amazon Delta region. The animals were predominantly from the river buffalo group breeds (Murrah, Mediterranean and Jafarabadi) and included males and females that were at least 12 months old, had meat production capacity, were of unknown reproductive status and lacked vaccination against leptospirosis.
Sampling was performed by convenience, and each sample was taken from a single kidney of each buffalo (total of 109 animals). The kidney capsule and surface were removed with the aid of sterile scalpels, and then a piece of approximately $10 \mathrm{~g}$ (both medullary and cortical parts) was collected with the aid of sterile forceps and scissors. The samples were individually stored in sterile plastic bags for homogenisation and subsequent bacteriological culturing.

\section{Bacteriological culturing for Leptospira isolation}

We used a culture medium adapted from Faine (1982). The medium was based on EMJH (Ellinghausen-McCulloughJohnson-Harris) enriched with $6 \%$ rabbit serum, $2 \%$ bovine serum albumin (BSA), Tween 80 and $2 \%$ foetal buffalo serum. Foetal buffalo serum was obtained after collecting blood from non-aborted foetuses at the slaughterhouse; subsequently, the blood was centrifuged, sterilised by filtration using a $0.22-\mu \mathrm{m}$ polyethersulfone (PES) membrane and inactivated at $56{ }^{\circ} \mathrm{C}$ for $1 \mathrm{~h}$. This medium was named LZB-USP-Buffalo (Laboratório de Zoonoses Bacterianas-Universidade de São Paulo) and was used in two forms, liquid and semi-solid, and the latter form contained agar $(0.15 \%)$ as a solidifying agent.

Kidney samples were macerated and diluted 1:10 in phosphate-buffered saline [PBS; $0.137 \mathrm{M} \mathrm{NaCl}, 0.0027 \mathrm{M}$ $\mathrm{KCl}, 0.01 \mathrm{M} \mathrm{Na}_{2} \mathrm{HPO}_{4}$ and $0.0018 \mathrm{M} \mathrm{KH}_{2} \mathrm{PO}_{4}$ (pH 7.4)], after which $1 \mathrm{~mL}$ of the diluted samples was seeded into 9 $\mathrm{mL}$ of liquid LZB-USP-Buffalo medium containing a selective Leptospira supplement (nalidixic acid, $50 \mathrm{mg} / \mathrm{L}$; cycloheximide, $100 \mathrm{mg} / \mathrm{L}$; chloramphenicol, $5 \mathrm{mg} / \mathrm{L}$ and neomycin, $5 \mathrm{mg} / \mathrm{L}$ ). The cultures were incubated at $30{ }^{\circ} \mathrm{C}$ in a bacteriological incubator for 12 to $24 \mathrm{~h}$ for decontamination, after which they were used to seed $1 \mathrm{~mL}$ in $9 \mathrm{~mL}$ of semi-solid LZB-USP-Buffalo medium without the selective supplements. Only the semi-solid LZB-USP-Buffalo media were then incubated at $30^{\circ} \mathrm{C}$ in a bacteriological incubator for 6 weeks and observed weekly under dark field microscopy for leptospires detection.

\section{Serological characterisation of isolates}

The isolates were serogrouped according to Faine et al. (1999) via microscopic agglutination test (MAT) using a panel of 21 hyperimmune rabbit antisera against Leptospira spp. (Royal Tropical Institute, Amsterdam, Netherlands) representing the most prevalent serogroups in Brazil: Semaranga (serovar: Patoc); Ballum (serovar: Castellonis); Tarassovi (serovar: Tarassovi); Australis (serovars: Australis and Bratislava); Sejroe (serovars: Hardjo-bovis, Sejroe, Hardjo-prajitno and Wolffi); Autumnalis (serovar: Autumnalis); Bataviae (serovar: Bataviae); Panama (serovar: Panama); Icterohaemorrhagiae (serovars: Icterohaemorrhagiae and Copenhageni); Canicola 
Fig. 1 Geographical location of the Amazon Delta region in Brazil

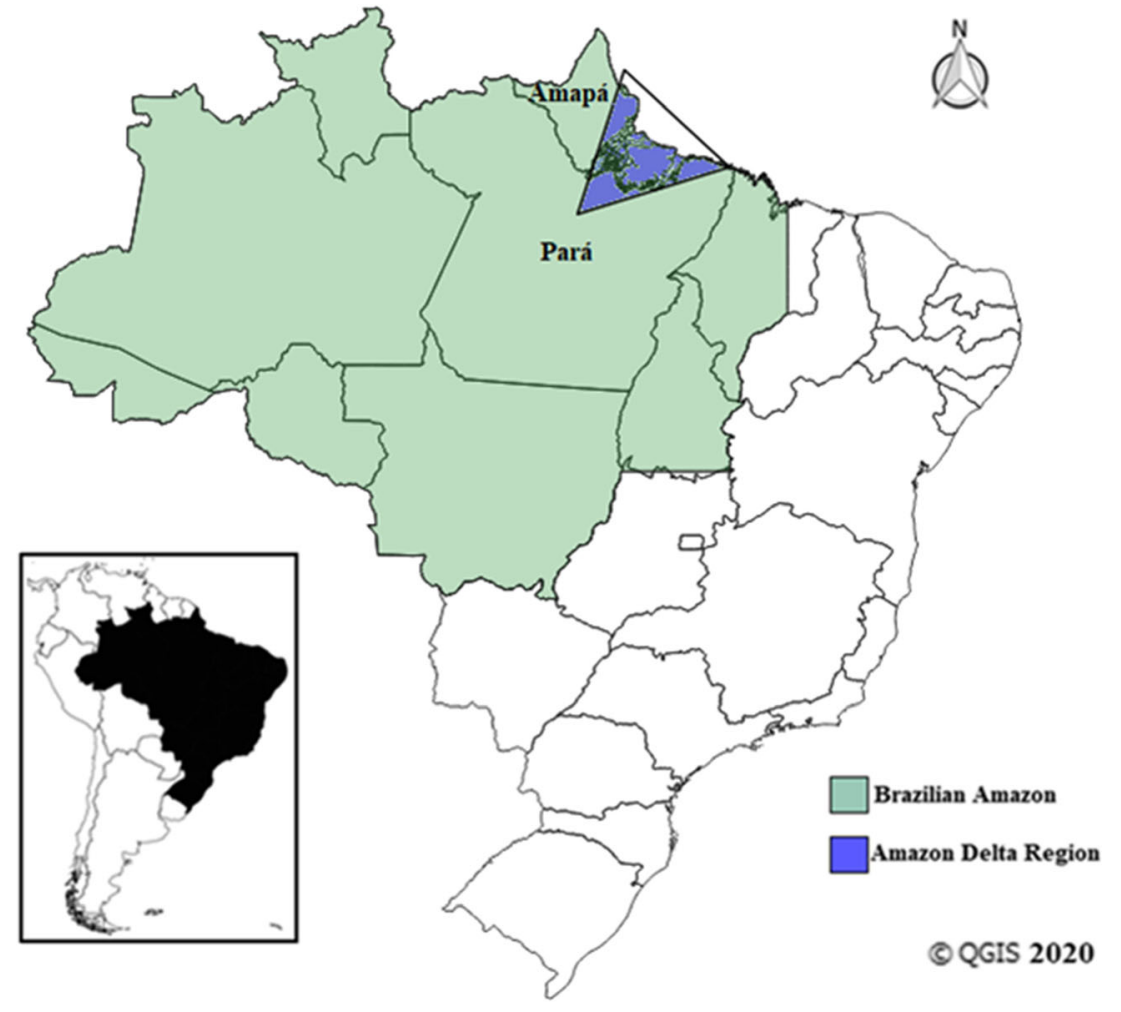

(serovar: Canicola); Cynopteri (serovar: Cynopteri); Hebdomadis (serovar: Hebdomadis); Pomona (serovar: Pomona); Pyrogenes (serovar: Pyrogenes); Djasiman (serovar: Sentot); and Grippotyphosa (serovar: Grippotyphosa).

\section{Molecular characterisation of isolates}

DNA extraction and purification from the isolates was performed using a PureLink ${ }^{\circledR}$ Genomic DNA Mini Kit (Invitrogen) following the manufacturer's protocol. For genus confirmation, the PCR amplification of Leptospira spp. was performed with the primers Lep1 and Lep2, which amplify a 330-bp region of the 16S rRNA gene (rrs) using GoTaq ${ }^{\mathrm{TM}}$ Green Master Mix (Promega, Brazil). The reaction occurred under the following conditions: an initial denaturation of $5 \mathrm{~min}$ at $94{ }^{\circ} \mathrm{C}, 40$ cycles of denaturation at 94 ${ }^{\circ} \mathrm{C}$ for $30 \mathrm{~s}$, annealing at $60{ }^{\circ} \mathrm{C}$ for $30 \mathrm{~s}$, extension at $72{ }^{\circ} \mathrm{C}$ for $30 \mathrm{~s}$ and a final primer extension of $72{ }^{\circ} \mathrm{C}$ for $5 \mathrm{~min}$ (Mérien et al. 1992).

Isolate typing was performed using a primer pair that amplified a 549-bp region of the $\sec Y$ gene and a primer pair that amplified a 600-bp region of the rроB gene. The reaction for the $\sec Y$ gene occurred under the following conditions: an initial denaturation of $3 \mathrm{~min}$ at $94{ }^{\circ} \mathrm{C}, 35$ cycles of denaturation at $94{ }^{\circ} \mathrm{C}$ for $30 \mathrm{~s}$, annealing at $55^{\circ} \mathrm{C}$ for $30 \mathrm{~s}$, and extension at $72{ }^{\circ} \mathrm{C}$ for $45 \mathrm{~s}$, and a final primer extension of $72{ }^{\circ} \mathrm{C}$ for $5 \mathrm{~min}$ (Ahmed et al. 2006). The reaction for the $r p o B$ gene occurred under the following conditions: an initial denaturation of 2 min at $95{ }^{\circ} \mathrm{C}, 33$ cycles of denaturation at $94{ }^{\circ} \mathrm{C}$ for $30 \mathrm{~s}$, annealing at $51{ }^{\circ} \mathrm{C}$ for $30 \mathrm{~s}$, and extension at 72 ${ }^{\circ} \mathrm{C}$ for $2 \mathrm{~min}$, and a final primer extension of $72{ }^{\circ} \mathrm{C}$ for $10 \mathrm{~min}$ (La Scola et al. 2006). L. interrogans serovar Hardjo-prajitno and ultrapure water were used as positive and negative controls, respectively, for all PCRs. The amplicons were analysed by electrophoresis on a $1.5 \%(\mathrm{w} / \mathrm{v})$ agarose gel, with $0.5 \mathrm{X}$ TBE as a running buffer $(0.045 \mathrm{M}$ Tris-borate, $1 \mathrm{mM}$ EDTA, pH 8.0). The gel was stained with SYBR Safe DNA gel stain (Invitrogen $($ ) and subsequently photographed under ultraviolet light with the aid of a transilluminator.

The amplicons were sequenced using the Sanger method with BigDye Terminator v.3.1 chemistry (Applied Biosystems) and an ABI-3500 automatic sequencer (Applied Biosystems). In a final $10 \mu \mathrm{L}$ reaction, $1 \mu \mathrm{L}$ of Big Dye, 1.5 $\mu \mathrm{L}$ of $5 \mathrm{X}$ buffer, $0.5 \mu \mathrm{L}$ of primer $(10 \mathrm{pM})$ and $7 \mu \mathrm{L}$ of the purified target DNA were used. The reaction conditions were as follows: an initial denaturation of $1 \mathrm{~min}$ at $96{ }^{\circ} \mathrm{C}$ and 40 cycles of denaturation at $96^{\circ} \mathrm{C}$ for $10 \mathrm{~s}$, annealing at $50^{\circ} \mathrm{C}$ for $5 \mathrm{~s}$ and extension at $60^{\circ} \mathrm{C}$ for $4 \mathrm{~min}$. Each product was sequenced with at least two replicates, one with the sense primer and the other with the antisense primer, increasing the reliability of the results.

The final product was precipitated using the ethanol/EDTA protocol provided by the manufacturer. Ten microlitres of HiDi formamide (Applied Biosystems ${ }^{\circledR}$ ) was added to the final precipitated product and submitted to denaturation step at 95 ${ }^{\circ} \mathrm{C}$ for $2 \mathrm{~min}$ and at $4{ }^{\circ} \mathrm{C}$ for $2 \mathrm{~min}$. 
The sequences were assembled using BioEdit Sequence Alignment Editor (Hall 1999). Phylogenetic trees were built using homologous sequences retrieved from GenBank (accession numbers in Figs. 2 and 3) with the neighbourjoining method, the Tamura-3-parameter model and 1000 bootstrap replicates in MEGA 7 (Kumar et al. 2016).

Multiple locus variable-number tandem repeat analysis (MLVA) was performed according to Salaün et al. (2006) using three discriminatory markers for the VNTR loci 4,7 and 10 (L. interrogans). The reaction occurred under the following conditions: an initial denaturation of $5 \mathrm{~min}$ at $94^{\circ} \mathrm{C}, 35$ cycles of denaturation at $94^{\circ} \mathrm{C}$ for $30 \mathrm{~s}$, annealing at $60^{\circ} \mathrm{C}$ for $30 \mathrm{~s}$, and extension at $72{ }^{\circ} \mathrm{C}$ for $1 \mathrm{~min}$, and a final primer extension at $72{ }^{\circ} \mathrm{C}$ for $10 \mathrm{~min}$.

\section{Results}

Of the 109 kidney samples assayed by bacteriological culturing, leptospires were observed in five samples by dark field microscopy and were confirmed by 16S PCR as members of the genus Leptospira. In the serogrouping analysis, all isolates were only reactive for the Pomona serogroup, with a titre of 25,600 .

DNA sequencing revealed that all isolates belonged to the species Leptospira interrogans (Figs. 2 and 3). The sequences were deposited in GenBank [accession numbers from MN901992 to MN901996 ( $\sec Y$ ) and MT042009 to MT042013 (rpoB)]. For the MLVA, all the isolates exhibited the same VNTR profile (4-1-10), which was previously described for strains of the Pomona serogroup (Miraglia et al. 2008; Zarantonelli et al. 2018).

The isolates were catalogued in the bank of national Leptospira isolates in the laboratory and were coded as follows: M51/19-70, M51/19-71, M51/19-72, M51/19-80 and M51/19-87. As the samples were collected by convenience, it was not possible to determine if the isolates were from animals of the same herd.

\section{Discussion}

The serogroup Pomona was first described in 1937 when a strain of Leptospira interrogans was isolated from the blood of a feverish patient during an outbreak in a dairy community near the city of Pomona, Australia (Clayton et al. 1937). Subsequently, this serogroup has been associated with pig leptospirosis, as pigs are considered to be natural carriers of the Pomona serovar (Faine et al. 1999). However, Pomona isolates are not restricted to pigs and have also been isolated from dogs (Mackintosh et al. 1980), cattle (Zarantonelli et al. 2018) and sheep (Hamond et al. 2019). In Brazil, Pomona isolates have been isolated from pigs (Miraglia et al. 2008) and wild animals (Silva et al. 2015) but have yet to be isolated from buffaloes.

The diffusion of the Pomona serogroup into buffaloes can be observed through serological studies that have demonstrated this serogroup to be one of the most prevalent in buffaloes in different countries (Konrad et al. 2013; Gloriani et al. 2016; Alamuri et al. 2019). Recently, a large serological study was carried out in buffaloes from the same area as this study (the Amazon Delta) and revealed that the Pomona serogroup was one of the most prevalent among the 20 evaluated serogroups. In addition, it has been suggested that other local and serologically distinct strains from the autochthonous Leptospira strains isolated in the Southeast region of Brazil may be circulating in buffaloes of the Amazon region (Guedes et al. 2020b).

Leptospiral DNA has been detected in aborted buffalo foetuses, and sequencing of this DNA has revealed the presence of L. interrogans with homology to the Pomona serogroup, among others (Marianelli et al. 2007). However, DNA sequencing is unable to discriminate serogroup-level leptospires,
Fig. 2 Phylogenetic analysis based on the partial $\sec Y$ gene of Leptospira isolates from buffalo kidneys (black circle). The tree was constructed with neighbourjoining method and Tamura-3 parameter model with bootstrap test of 1000 replicates

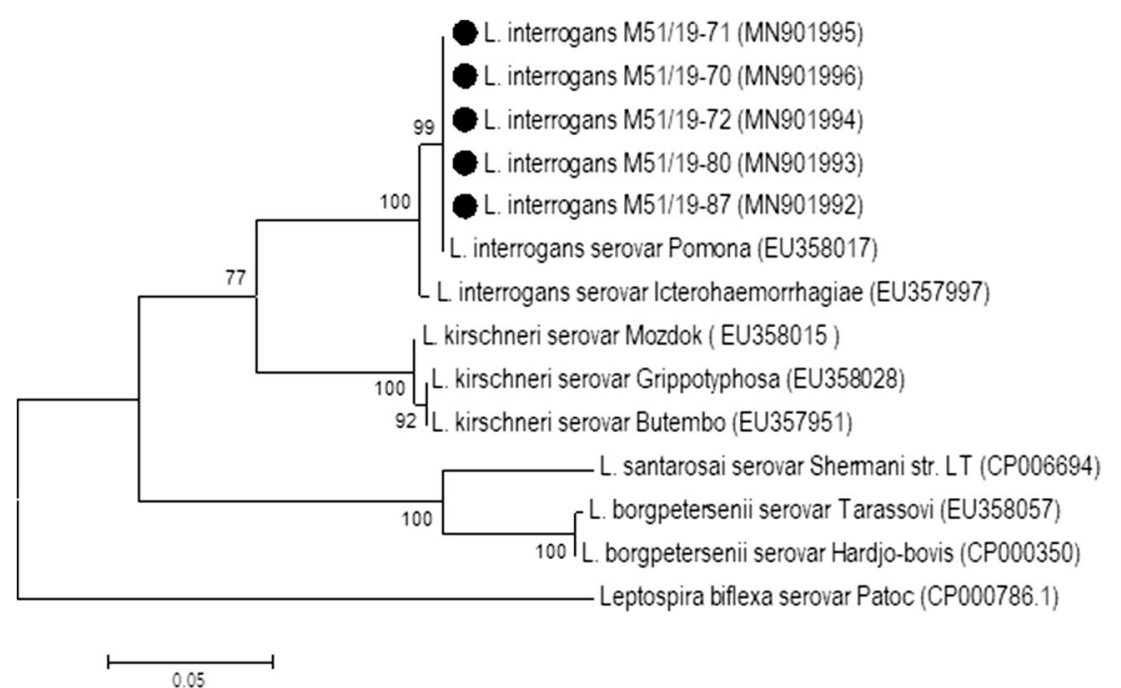


Fig. 3 Phylogenetic analysis based on the partial $r p o B$ gene of Leptospira isolates from buffalo kidneys (black circle). The tree was constructed with neighbourjoining method and Tamura-3 parameter model with bootstrap test of 1000 replicates

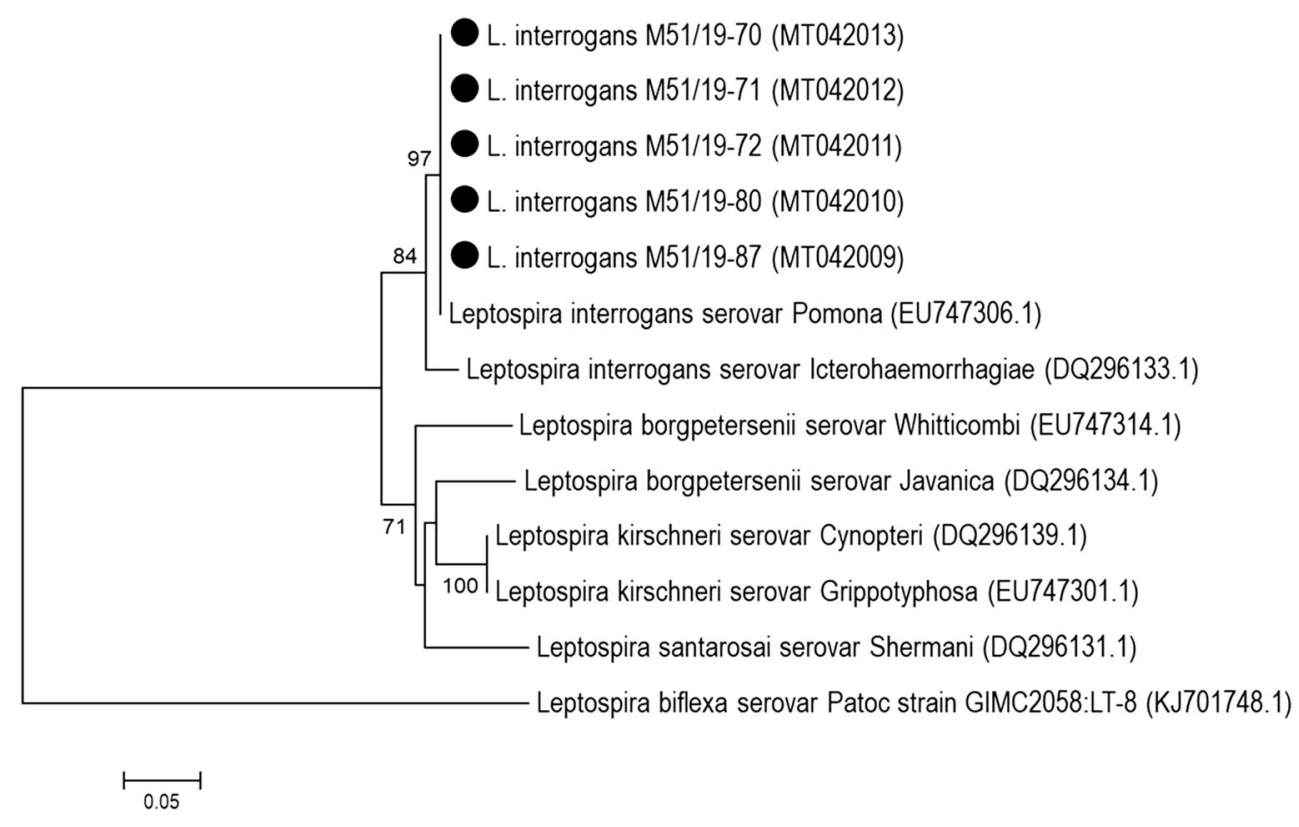

as these are distinct classifications (Faine et al. 1999). In the face of this evidence, whether serogroup Pomona commonly infects buffaloes remains unknown since the isolation of Leptospira belonging to this serogroup in buffalo is rare.

Leptospirosis in buffaloes is a problem for both animal and public health, especially in flooded areas, such as those present in Asian countries. In these regions, buffaloes are used in rice farming in flooded fields, suggesting that these animals may be related to cases of human leptospirosis (Agampodi et al. 2011). In a previous study, leptospiral DNA, mainly L. interrogans, was detected in buffalo kidneys slaughtered in the Amazon Delta region (Guedes et al. 2020a). This reinforces the condition that these animals can be infected by Leptospira and the bacteria can be eliminated in urine, maintaining the microorganisms in the environment. Furthermore, in this region, buffaloes are part of the local culture, where they come into close contact with humans, which should be taken into consideration when adopting disease control measures for these animals.

Despite the small number of obtained isolates $(5 / 109)$, this does not reflect the real infection rate of buffaloes by leptospires, since bacteriological culturing normally has low sensitivity due to several limitations such as sampling, material processing, bacterial fragility in biological samples and contamination of the material during the extended incubation period (Faine et al. 1999; Levett 2001).

In this study, we used a culture medium in which we included foetal buffalo serum associated with bovine serum albumin (BSA), Tween 80 and rabbit serum as enrichment. Chideroli et al. (2017) reported the isolation of Leptospira strains from cattle using modified EMJH medium with added foetal bovine serum and sodium pyruvate. However, the authors described that only the addition of foetal bovine serum to fully replace the rabbit serum was critical for primary isolation but did not promote a cellular increase in subsequent cultures. In this way, we also observed that initially, the isolates did not grow in culture media without the addition of foetal buffalo serum and required five to ten consecutive passages in EMJH and Fletcher media for adaptation (data not shown).

In this work, the presence of strains from the Pomona serogroup would indicate that pigs may be involved in the transmission of these bacteria, primarily because pigs are adapted to strains belonging to this serogroup and are natural carriers of it (Faine et al. 1999). Nevertheless, in the region investigated in this study, it is uncommon to note swine production associated with buffalo. This observation suggests that the source of infection of these animals may involve wild animals such as capybaras (Hydrochaeris hydrochaeris), which are commonly found in the Amazon region in rivers, puddles and dams together with buffaloes. Thus, capybaras may play an important role as a carrier of leptospires in the environment, since it has been shown that capybaras experimentally infected with L. interrogans serovar Pomona developed leptospiruria (Marvulo et al. 2009).

As it was not possible to determine if the isolates were from animals with clinical signs suggestive of leptospirosis, or whether they were associated with animal reproductive status or not, the possibility that these isolates could be adapted to and maintained in buffaloes in the region should be considered. For example, bovines may harbour strains of the serovars Pomona and Grippotyphosa (Faine et al. 1999), which are not considered to be adapted to them, and the identification of different Leptospira strains in bovines without clinical signs demonstrates the adaptability that these bacteria may have in the host (Pinto et al. 2017). 


\section{Conclusion}

The Brazilian Amazon comprises many remote and heterogeneous regions that are formed by numerous rivers, islands and islets, where buffaloes have a strong cultural and economic influence. However, the difficult accessibility and lack of laboratory structures in the region reflect the lack of studies regarding the health of these animals. The present study reports the first isolation and characterisation of Leptospira from buffalo raised in the Brazilian Amazon and identifies five isolates belonging to the Pomona serogroup, adding to knowledge of buffalo leptospirosis, which is poorly studied worldwide when compared to cattle leptospirosis. These results also show that in the Amazon, buffaloes can be infected by strains of leptospires other than those of the Sejroe serogroup, which is considered to be more common and adapted to cattle.

Acknowledgements $\mathrm{MBH}$ thanked $\mathrm{CNPq}$ (Conselho Nacional de Desenvolvimento Científico e Tecnológico) for the fellowship (CNPq 309146/2017-8). IBG thanked CAPES (Coordenação de Aperfeiçoamento de Pessoal de Nível Superior) for the scholarship.

Funding This study was financed in part by CAPES (Coordenação de Aperfeiçoamento de Pessoal de Nível Superior), Brasil-Finance Code 001 and by $\mathrm{CNPq}$ (Conselho Nacional de Desenvolvimento Científico e Tecnológico) (420110/2018-6).

\section{Declarations}

Ethics approval This study was approved by the Ethics Committee on Animal Use of the School of Veterinary Medicine and Animal Science (Universidade de São Paulo) - CEUA/FMVZ no. 5613211118.

Conflict of interest The authors declare no competing interests.

\section{References}

Agampodi, S.B., Peacock, S.J., Thevanesam, V., Nugegoda, D.B., Smythe, L., Thaipadungpanit, J., Craig, S.B., Burns, M.A., Dohnt, M., Boonsilp, S., Senaratne, T., Kumara, A., Palihawadana, P., Perera, S., Vinetz, J.M., 2011. Leptospirosis Outbreak in Sri Lanka in 2008: Lessons for Assessing the Global Burden of Disease, The American Journal of Tropical Medicine and Hygiene, 85, 471-478.

Ahmed, N., Devi, S.M., Valverde, M.D.L.Á., Vijayachari, P., Machang, R.S., Ellis, W., Hartskeerl, R.A., 2006. Multilocus sequence typing method for identification and genotypic classification of pathogenic Leptospira species, Annals of Clinical Microbiology and Antimicrobials, 5, 28.

Alamuri, A., Thirumalesh, S.R.A., Kumari, S.S., Kumar, K.V., Roy, P., Balamurugan, V., 2019. Seroprevalence and distribution of serogroup-specific pathogenic Leptospira antibodies in cattle and buffaloes in the state of Andhra Pradesh, India, Veterinary World, $12,1212-1217$.

Assenga, J.A., Matemba, L.E., Muller, S.K., Mhampi, G.G., Kazwala, R.R., 2015. Predominant Leptospiral Serogroups Circulating among
Humans, Livestock and Wildlife in Katavi-Rukwa Ecosystem, Tanzania, PLoS Neglected. Tropical Diseases, 9, e0003607.

Balakrishnan, G., Meenambigai, T.V., Roy, P., 2014. Diagnosis of Bovine Leptospirosis by $16 \mathrm{~s}$ rRNA Based Polymerase Chain Reaction, The Indian Journal of field veterinarians, 10, 87-88.

Chideroli, R.T., Gonçalves, D.D., Suphoronski, S.A., Alfieri, A.F., Alfieri, A.A., Oliveira, A.G., Freitas, J.C., Pereira, U.P., 2017. Culture Strategies for Isolation of Fastidious Leptospira Serovar Hardjo and Molecular Differentiation of Genotypes Hardjobovis and Hardjoprajitno, Frontiers in Microbiology, 8, 2155.

Clayton, G.E.B., Derrick, E.H., Cilento, R., 1937. The presence of leptospirosis of a mild type, seven day fever in Queensland, The Medical Journal of Australia, 24, 647-653.

Faine, S., 1982. Guidelines for the control of leptospirosis, (WHO offset publication, Geneva).

Faine, S., Adler, B., Bolin, C., Perolat, P., 1999. Leptospira and Leptospirosis. 2nd ed. (MediSci, Melbourne).

Gloriani, N.G., Villanueva, S.Y.A.M., Yanagihara, Y., Yoshida, S.I., 2016. Identification of prevalent Leptospira serovars infecting water buffaloes, cows, dogs, pigs, and rats in the Philippines, The Southeast Asian Journal of Tropical Medicine and Public Health, 47, 766-73.

Guedes, I.B., Araújo, S.A.A., Souza, G.O., Silva, S.O.S., Taniwaki, S.A., Cortez, A., Brandão, P.E., Heinemann, M.B., 2019. Circulating Leptospira species identified in cattle of the Brazilian Amazon, Acta Tropica, 191, 212-216.

Guedes, I.B., Souza, G.O., Castro, J.F.P., Souza-Filho, A.F., Cavalini, M.B., Taniwaki, S.A., Maia, A.L.P., Pereira, I.C., Heinemann, M.B., 2020a. Identification of Pathogenic Leptospira Species in the Urogenital Tract of Water Buffaloes (Bubalus bubalis) From the Amazon River Delta Region, Brazil, Frontiers in Veterinary Science, 7, 269.

Guedes, I.B., Souza, G.O., Oliveira, L.A.R., Castro, J.F.P., Souza-Filho, A.F., Maia, A.L.P., Heinemann, M.B., 2020b. Prevalence of Leptospira serogroups in buffaloes from the Brazilian Amazon, Veterinary Medicine and Science, 6, 433-440.

Hall, T.A., 1999. BioEdit: a user-friendly biological sequence alignment editor and analysis program for Windows 95/98/NT, Nucleic Acids Symposium Series, 41, 95-98.

Hamond, C., Silveira, C.S., Buroni, F., Suanes, A., Nieves, C., Salaberry, X., Aráoz, V., Costa, R.A., Rivero, R., Giannitti, F., Zarantonelli, L., 2019. Leptospira interrogans serogroup Pomona serovar Kennewicki infection in two sheep flocks with acute leptospirosis in Uruguay, Transboundary and Emerging Diseases, 66, 1186-1194.

Konrad, J.L., Campero, L.M., Caspe, G.S., Brihuega, B., Draghi, G., Moore, D.P., Crudeli, G.A., Venturini, M.C., Campero, C.M., 2013. Detection of antibodies against Brucella abortus, Leptospira spp., and Apicomplexa protozoa in water buffaloes in the Northeast of Argentina, Tropical Animal Health and Production, 45, 17511756.

Kumar, S., Stecher, G., Tamura, K., 2016. MEGA7: Molecular Evolutionary Genetics Analysis version 7.0 for bigger datasets, Kumar, S., Stecher, G., Tamura, K., 2016. MEGA7: Molecular Evolutionary Genetics Analysis version 7.0 for bigger datasets, Molecular Biology and Evolution, 33, 1870-1874.

La Scola, B., Bui, L.T., Baranton, G., Khamis, A., Raoult, D., 2006. Partial rpoB gene sequencing for identification of Leptospira species, FEMS Microbiology Letters, 263, 142-147.

Levett, P.N., 2001. Leptospirosis, Clinical Microbiology Reviews, 14, 296-326.

Loureiro, A.P., Hamond, C., Pinto, P., Bremont, S., Bourhy, P., Lilenbaum, W., 2016. Molecular analysis of leptospires from serogroup Sejroe obtained from asymptomatic cattle in Rio de Janeiro - Brazil reveals genetic proximity to serovar Guaricura, Research in Veterinary Science, 105, 249-253. 
Mackintosh, C.G., Blackmore, D.K., Marshal, R.B., 1980. Isolation of Leptospira interrogans serovars Tarassovi and Pomona from dogs, New Zealand Veterinary Journal, 28, 100.

Marianelli, C., Tarantino, M., Astarita, S., Martucciello, A., Capuano, F., Galiero, G., 2007. Molecular detection of Leptospira species in aborted fetuses of water buffalo, The Veterinary Record, 161, 310-311.

Marvulo, M.F.V., Silva, J.C.R., Ferreira, P.M., Morais, Z.M., Moreno, A.M., Doto, D.S., Paixão, R., Baccaro, M.R., Vasconcellos, S.A., Ferreira-Neto, J.S., 2009. Experimental leptospirosis in capybaras (Hydrochaeris hydrochaeris) infected with Leptospira interrogans serovar Pomona, Journal of Zoo and Wildlife Medicine, 40, 726-730.

Mérien, F., Amouriaux P., Perolat, P., Baranton, G., Saint-girons, I., 1992. Polymerase chain reaction goes detection of Leptospira spp. in clinical samples, Journal of Clinical Microbiology, 30, 22192224.

Miraglia, F., Moreno, A.M., Gomes, C.R., Paixão, R., Liuson, E., Morais, Z.M., Maiorka, P., Seixas, F.K., Dellagostin, O.A., Vasconcellos, S.A., 2008. Isolation and characterization of Lepospira interrogans form pigs slaughtered in São Paulo State, Brazil. Brazilian Journal of Microbiology, 39, 501-507.

Pimenta, C.L.R., Bezerra, C.S., Morais, D.A., Silva, M.L.C.R., Nogueira, D.B., Costa, D.F., Santos, C.S.A.B., Higino, S.S.S., Alves, C.J., Azevedo, S.S., 2019. Seroprevalence and predominant serogroups of Leptospira sp. in serological tests of ruminants in northeastern Brazil, Semina: Ciências Agrárias, 40, 1512-1522.

Pinto, P.S., Pestana, C., Medeiros, M.A., Lilenbaum, W., 2017. Plurality of Leptospira strains on slaughtered animals suggest a broader concept of adaptability of leptospires to cattle, Acta Tropica, 172, 156159.

Rocha, K.S., Lima, M.S., Paz, G.S., Langoni, H., Moraes, C.C.G., 2019. Detecção de anticorpo anti-Brucella sp. e anti- Leptospira spp. em búfalos (Bubalus bubalis) abatidos em matadouro na cidade de Belém, Pará, Revista de Ciências Agrárias, 62.

Salaün, L., Mérien, F., Gurianova, S., Baranton, G., Picardeau, M., 2006. Application of Multilocus Variable-Number Tandem-Repeat analysis for molecular typing of the agent of leptospirosis. Journal of Clinical Microbiology, 44, 3954-3962.

Silva, F.J., Santos, C.E.P., Silva, T.R., Silva, G.C.P., Loeffler, S.G., Brihuega, B., Alarcon, M.F.F., Curci, V.C.M., Mathias, L.A.,
2015. Search of leptospires and of antibodies against leptospires in animals and human beings in farms in Pantanal and Caatinga Brazilian biomes, Brazilian Journal of Veterinary Research and Animal Science, 52, 234-248.

Thibeaux, R., Iraola, G., Ferrés, I., Bierque, E., Girault, D., SoupéGilbert, M.E., Picardeau, M., Goarant, C., 2018. Deciphering the unexplored Leptospira diversity from soils uncovers genomic evolution to virulence, Microbial Genomics, 4.

Vasconcellos, S.A., Oliveira, J.C.F., Morais, Z.M., Baruselli, P.S., Amaral, R., Pinheiro, S.R., Ferreira, F., Ferreira-Neto, J.S., Schönberg, A., Hartskeerl, R., 2001. Isolation of Leptospira santarosai, serovar Guaricura from buffaloes (Bubalus bubalis) in Vale do Ribeira, São Paulo, Brazil, Brazilian Journal of Microbiology, 32, 298-300.

Viana, R.B., Del Fava, C., Moura, A.C.B., Cardoso, E.C., De Araújo, C.V., Monteiro, B.M., Pituco, E.M., Vasconcellos, S.A., 2009. Ocorrência de Anticorpos anti- Neospora caninum, Brucella sp. e Leptospira spp. em Búfalos (Bubalus bubalis) criados na Amazônia, Arquivos do Instituto Biológico, 76, 453-457.

Vincent, A.T., Schiettekatte, O., Goarant, C., Neela, V.K., Bernet, E., Thibeaux, R., Ismail, N., Khalid, M.K.N.M., Amran, F., Masuzawa, T., Nakao, R., Korba, A.A., Bourhy, P., Veyrier, F.J., Picardeaus, M., 2019. Revisiting the taxonomy and evolution of pathogenicity of the genus Leptospira through the prism of genomics, PLoS Neglected. Tropical Diseases, 13, e0007270.

Zarantonelli, L., Suanes, A., Meny, P., Buroni, F., Nieves, C., Salaberry, X., Briano, C., Ashfield, N., Silveira, C.S., Dutra, F., Easton, C., Fraga, M., Giannitti, F., Hamond, C., Marcías-Rioseco, M., Menéndez, C., Mortola, A., Picardeau, M., Quintero, J., Ríos, C., Rodríguez, Romero, A., Varela, G., Rivero, R., Schelotto, F., RietCorrea, F. Buschiazzo, A., 2018. Isolation of pathogenic Leptospira strains from naturally infected cattle in Uruguay reveals high serovar diversity, and uncovers a relevant risk for human leptospirosis, PLoS Neglected. Tropical Diseases, 12, e0006694.

Publisher's Note Springer Nature remains neutral with regard to jurisdictional claims in published maps and institutional affiliations. 